\title{
C-BUTYLCALIX[4]RESORCINARENE OCTABENZOATE AND OCTASINNAMATE: THE SYNTHESIZED SUNSCREEN COMPOUNDS
}

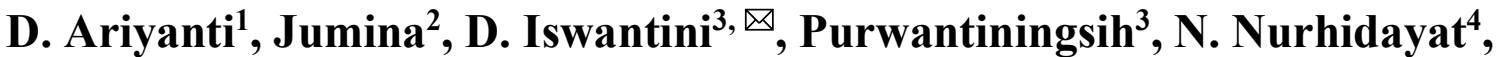 \\ H. Effendi ${ }^{5}$ and F.G. Athaya ${ }^{2}$ \\ ${ }^{1}$ Study Program of Natural Resources and Environmental Management Sciences, IPB University, \\ Bogor 16680, Indonesia \\ ${ }^{2}$ Department of Chemistry, Universitas Gadjah Mada, Yogyakarta 55281, Indonesia \\ ${ }^{3}$ Department of Chemistry, IPB University, Bogor 16680, Indonesia \\ ${ }^{4}$ Laboratory of Microbiology and Healthcare Central Research Department of Biology, \\ Indonesian Institute of Sciences (LIPI), Bogor 16911, Indonesia \\ ${ }^{5}$ Center of Environmental Research, IPB University, Bogor 16680, Indonesia \\ Corresponding Author: dyahprado@gmail.com
}

\begin{abstract}
C-butylcalix[4]resorcinarene octabenzoate and octacinnamate have been synthesized and evaluated as absorbers for ultraviolet radiation. The C-butylcalix[4]resorcinarene (CBCR) was synthesized from resorcinol and pentanal using $\mathrm{HCl}$ as a catalyst in ethanol at $78^{\circ} \mathrm{C}$ for $24 \mathrm{~h}$ to give $\mathrm{CBCR} 97 \%$ in yield. Synthesis of C-butylcalix[4]resorcinarene octabenzoate (CBCROB) and C-butylcalix[4]resorcinarene octacinnamate (CBCROC) were carried out via esterification of the CBCR with benzoyl chloride in pyridine at $60{ }^{\circ} \mathrm{C}$ for $2 \mathrm{~h}$, producing CBCROB and CBCROC giving 46 and $66 \%$ yield, respectively. The chemical structure of all products was elucidated using FTIR and ${ }^{1} \mathrm{H}-$ NMR spectrometers. Furthermore, the sun protection factor (SPF) value and photostability of the synthesized compounds were determined based on UV-Vis spectrophotometer and lighting under UV lamp (intensity $0.27 \mathrm{mWcm}^{-}$ $\left.{ }^{2}\right)$ over various time of $15,30,60,90$, and $120 \mathrm{~min}$. The UV spectroscopic result and calculation gave the SPF value of CBCR, CBCROB, and CBCROC at $50 \mathrm{ppm}$ concentrations were 3.80, 1.78, and 380, respectively. Therefore, CBCROC could be used as a sunscreen compound, especially within the UV-B region.
\end{abstract}

Keywords: Sunscreen, Calix[4]resorcinarene, Benzoate, Cinnamate, SPF.

RASĀYAN J. Chem., Vol. 14, No.2, 2021

\section{INTRODUCTION}

UV rays are a part of the sunlight (7\%) as the greatest energy source for living organisms on Earth. The UV ray can also be used as phototherapy ${ }^{1}$ and it can induce the skin to produce vitamin D3, as deficiency of vitamin D3 may increase the risk of several diseases, such as bone disease, cancer, and also heart disease. ${ }^{2}$ However, UV also has adverse effects for living organisms such as erythema ${ }^{3}$, dark color $\operatorname{skin}^{4}$, melanoma ${ }^{5}$, accelerating skin aging ${ }^{6}$, and skin cancer. ${ }^{7}$

UV rays can be divided into three sections, i.e. UVA (315-400 nm), UVB (280-315 nm), and UVC (200-280 nm). ${ }^{8}$ UVA and UVB are harmful to the earth because they can penetrate the ozone atmosphere, but UVC cannot reach the Earth's surface if the ozone layer is safe. ${ }^{9}$ To decrease this harmfulness of the UVA and UVB, some researchers developing sunscreen compounds. In particular, sunscreens to absorb UV rays ${ }^{10}$ are xanthone ${ }^{11}$, chalcone ${ }^{12,13}$, lignin ${ }^{14,15}$, and benzophenone. ${ }^{16}$ The compound with greater electron conjugation in its chemical structure is believed to have better UV-ray absorption ability. ${ }^{17}$

Calixarenes are stable macromolecules with unique geometry like flower vases or crowns. Besides this unique shape, the modified calixarenes usually have functional groups to be able to absorb UV rays (e.g. $\mathrm{OH},-\mathrm{COOH}$, and $-\mathrm{NH} 2)^{18}$ and also great electron delocalization. ${ }^{19,20}$ Thus, the calixarenes have great potential to be applied as sunscreen. Furthermore, the calixarenes usually have a high molecular weight 
RASĀYAN J. Chem.

Vol. 14 | No. 3 |1521-1527| July - September | 2021

preventing the sunscreen to be absorbed into the $\operatorname{skin}^{21}$ and give the molecules high chemical and thermal stability ${ }^{22}$ as well.

In this work, C-butylcalix[4]resorcinarene was synthesized from resorcinol and pentanal, and then it was modified using benzoyl chloride and cinnamoyl chloride to produce C-butylcalix[4] resorcinarene octabenzoate and C-butylcalix[4]resorcinarene octacinnamate, respectively. Afterward, these synthesized compounds were assayed as sunscreen candidates. The synthesized products are novel compounds and no one has ever published elsewhere.

\section{EXPERIMENTAL}

\section{Materials and Instrumentations}

Resorcinol, pentanal, benzoyl chloride, ethanol, ethyl acetate, pyridine, hydrochloric acid (37 wt\%), and sodium sulfate anhydrous were obtained from Merck.

The apparatus used in characterizing the synthesized products were a melting point apparatus (Electrothermal 9100), an FTIR spectrometer (FTIR, Shimadzu Prestige 21), a ${ }^{1} \mathrm{H}-\mathrm{NMR}$ (NMR, JEOL JSM6510LA $500 \mathrm{MHz}$ ), an LCMS (Waters Alliance), a UV-Vis spectrophotometer (Shimadzu UV spectrophotometer UV-1800), a UVB lamp, and a phototherapy controller.

\section{Synthesis of CBCR}

Resorcinol (5.50 g; $0.05 \mathrm{~mol}$ ) was dissolved in $25 \mathrm{~mL}$ ethanol 97\%. To the mixture, $1.5 \mathrm{~mL} \mathrm{HCl} \mathrm{37 \%} \mathrm{was}$ added and stirred until homogeneous. The mixture was cooled to $15{ }^{\circ} \mathrm{C}$, and pentanal $(4.30 \mathrm{~g} ; 0.05 \mathrm{~mol})$ was added and kept for $24 \mathrm{~h}$. When the temperature system reached room temperature, the obtained solid was filtered and washed with distilled water until the $\mathrm{pH}$ of the filtrate was neutral. The product's melting point was determined by using melting point apparatus, while the chemical structure of the product was characterized by using FTIR and 1H-NMR spectrometers.

\section{Synthesis of CBCROB and CBCROC}

CBCR (3.31 g; $4.60 \mathrm{mmol}$ ) was dissolved in $22.70 \mathrm{~mL}$ pyridine, followed with benzoyl chloride (10.34 $\mathrm{mL} ; 73.60 \mathrm{mmol}$ ) addition, and the mixture was kept in an ice bath. Afterward, the mixture was stirred and heated at $60{ }^{\circ} \mathrm{C}$ for $2 \mathrm{~h}$. The mixture was left to reach room temperature and was acidified by $\mathrm{HCl} 10 \%$. Furthermore, the sample was extracted using $10 \mathrm{~mL}$ ethyl acetate and saturated $\mathrm{NaCl}$ solution $1-2 \mathrm{~mL}$ (three times repetition), and was extracted with $10 \mathrm{~mL}$ of $10 \% \mathrm{NaOH}$ solution and $10 \mathrm{~mL}$ distilled water, sequentially. The filtrate was dried by sodium sulfate anhydrous and then evaporated, giving the CBCROB. For the synthesis of CBCROC, the benzoyl chloride was replaced by cinnamoyl chloride $(12.26 \mathrm{~mL}, 73.60$ mmol). The desired compounds were characterized by using FTIR and 1H-NMR spectrometers.

\section{Detection Method}

\section{In Vitro Tests Using Spectroscopic Methods}

The in vitro test using spectroscopy of the sample was conducted as reported by Walters et al. ${ }^{23}$ The CBCR, CBCROB, and CBCROC compounds were weighed $(1 \mathrm{mg}$ ), dissolved into $20 \mathrm{~mL}$ of ethyl acetate (solution concentration was $50 \mathrm{ppm}$ ). The absorbance of the test solution was measured by a UV-Vis spectrophotometer from 200 to $400 \mathrm{~nm}$. Ethyl acetate was used as a blank solution. The compounds that have strong absorption in the UVB or UVA range area will be tested for their photostability.

\section{Photostability Test}

The photostability test of products was carried as reported by Chawla et al. ${ }^{21}$ CBCROC $(0.40 \mathrm{mg})$ was transferred in $50 \mathrm{~mL}$ graduated cylinder, ethyl acetate was added up to fill up the cylinder, to obtain $8 \mathrm{ppm}$ concentration. Each test solution was irradiated using UVB. $0.27 \mathrm{mWcm}^{-2}$ for various times $(0,15,30,60$, 90 , and $120 \mathrm{~min}$ ). Following irradiation, the CBCROC solution absorbance was measured at its optimum wavelength using a UV-Vis spectrophotometer. Ethyl acetate was used as a blank. The compounds that displayed a significant increase of absorbance after irradiation with UVB were chosen as sunscreen candidates. 
RASĀYAN J. Chem.

Vol. 14 | No. 3 |1521-1527| July - September | 2021<smiles>Oc1cccc(O)c1</smiles>

Resorcino1

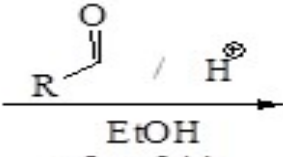

reflux $24 \mathrm{~h}$, $78{ }^{\circ} \mathrm{C}$<smiles>[R]C1c2cc(c(O)cc2O)C([R])c2cc(c(O)cc2O)C([R])c2cc(c(O)cc2O)C([R])c2cc1c(O)cc2O</smiles>

CBCR

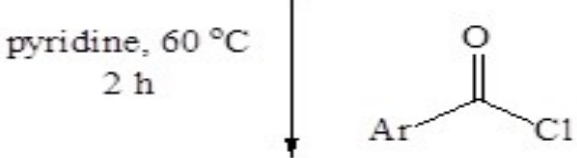

note: $\mathrm{R}=\mathrm{n}-\mathrm{C}_{4} \mathrm{H}_{9}$ $\mathrm{Ar}=\mathrm{C}_{6} \mathrm{H}_{5}, \mathrm{C}_{6} \mathrm{H}_{5}-\mathrm{CH}=\mathrm{CH}$

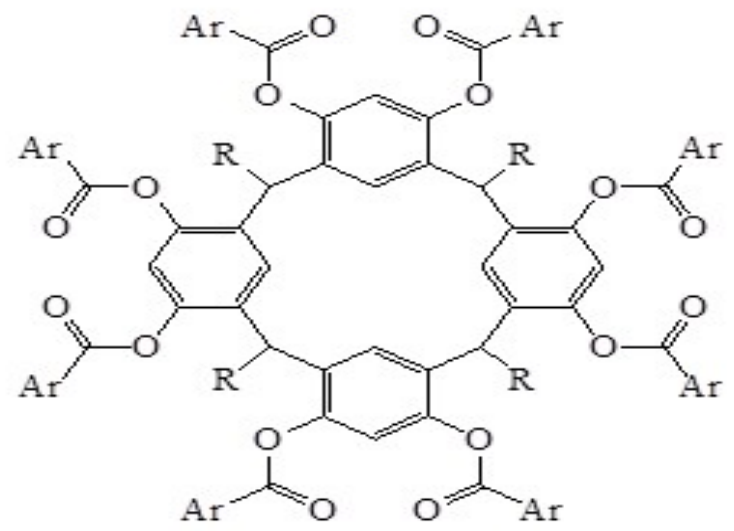

CBCROB or CBCROC

Scheme-1: The Synthetic Reaction of CBCR, CBCROB, and CBCROC

\section{RESULTS AND DISCUSSION}

\section{Synthesized CBCR}

The CBCR was obtained as a yellow solid $(97 \%)$, melting point $340-345^{\circ} \mathrm{C}$. This high melting point can be explained by the presence of strong intermolecular hydrogen bonds between the $-\mathrm{OH}$ groups in the CBCR, as indicated by the FTIR and 1H-NMR spectra. The FTIR spectra showed a strong broadened of $\mathrm{O}-\mathrm{H}$ peak $\left(3310 \mathrm{~cm}^{-1}\right)$. The $\mathrm{C}-\mathrm{H}$ stretching and $\mathrm{C}-\mathrm{H}$ bending appeared at 2932 and $1443 \mathrm{~cm}^{-1}$, respectively, and also twin peaks at 1620 and $1504 \mathrm{~cm}^{-1}$, indicating $\mathrm{C}=\mathrm{C}$ absorption of aromatic rings. The absorption at $1296 \mathrm{~cm}^{-1}$ is designated for the $\mathrm{C}-\mathrm{O}$ group. This explanation of the CBCR FTIR spectra confirms the CBCR structure as well the $1 \mathrm{H}-\mathrm{NMR}$ spectrum that is presented in Fig.-1. It shows the proton resonance of $-\mathrm{CH}_{3}$ $(0.85 \mathrm{ppm}),-\mathrm{CH}_{2}(1.30$ and $2.02 \mathrm{ppm}),-\mathrm{CH}$ bridge of calix[4]resorcinarene (4.21 ppm), aromatic (6.17 and $7.14 \mathrm{ppm})$, and hydroxyl (8.88 ppm) of the CBCR.

\section{Synthesized CBCROB}

The mole ratio between CBCR and the excess benzoyl chloride was 1:16. The reaction was carried out at $60{ }^{\circ} \mathrm{C}$. These 8 hydrogen moieties of CBCR were able to be substituted by the benzoyl group originated from the benzoyl chloride. The CBCROB was formed as a brownish gel in $46 \%$ yield. The characteristic peaks of the CBCROB FTIR spectra: $\mathrm{C}=\mathrm{O}$ ester $\left(1736 \mathrm{~cm}^{-1}\right)$ and $\mathrm{C}-\mathrm{O}$ ester $\left(1265 \mathrm{~cm}^{-1}\right)$ indicated that the intended product has been successfully synthesized. The $1 \mathrm{H}-\mathrm{NMR}$ spectrum $\left(\mathrm{CDCl}_{3}\right.$ solvent) of the compound was displayed in Fig.-2. It showed the proton resonance of $-\mathrm{CH}_{3}(0.84 \mathrm{ppm}),-\mathrm{CH}_{2}(1.24$ and 
RASĀYAN J. Chem.

Vol. 14 | No. 3 |1521-1527| July - September | 2021

$2.04 \mathrm{ppm})$, proton bridge calix[4]-resorcinarene (4.12 ppm), aromatic of benzoyl group (7.45 ppm), and aromatic benzene (7.24 and $8.65 \mathrm{ppm})$. This ${ }^{1} \mathrm{H}-\mathrm{NMR}$ result proves that the $\mathrm{CBCROB}$ compound has been successfully synthesized.

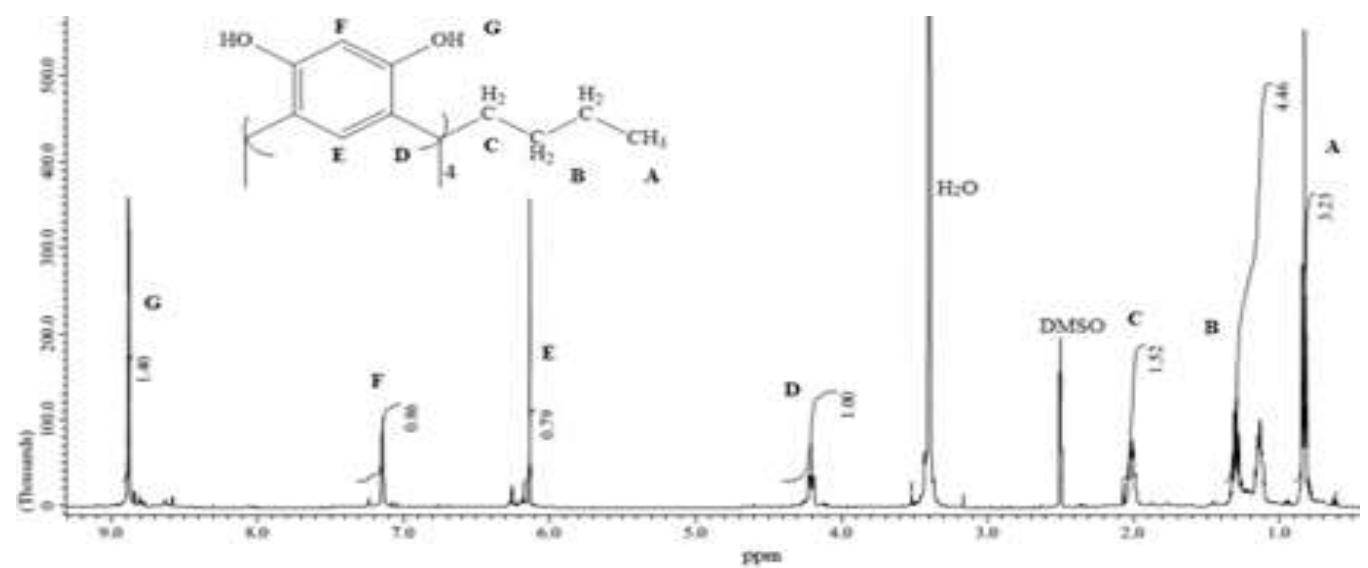

Fig.-1: ${ }^{1} \mathrm{H}$ NMR (500 MHz) Spectra for $\mathrm{CBCR}$ in $\mathrm{CD}_{3} \mathrm{OD}$

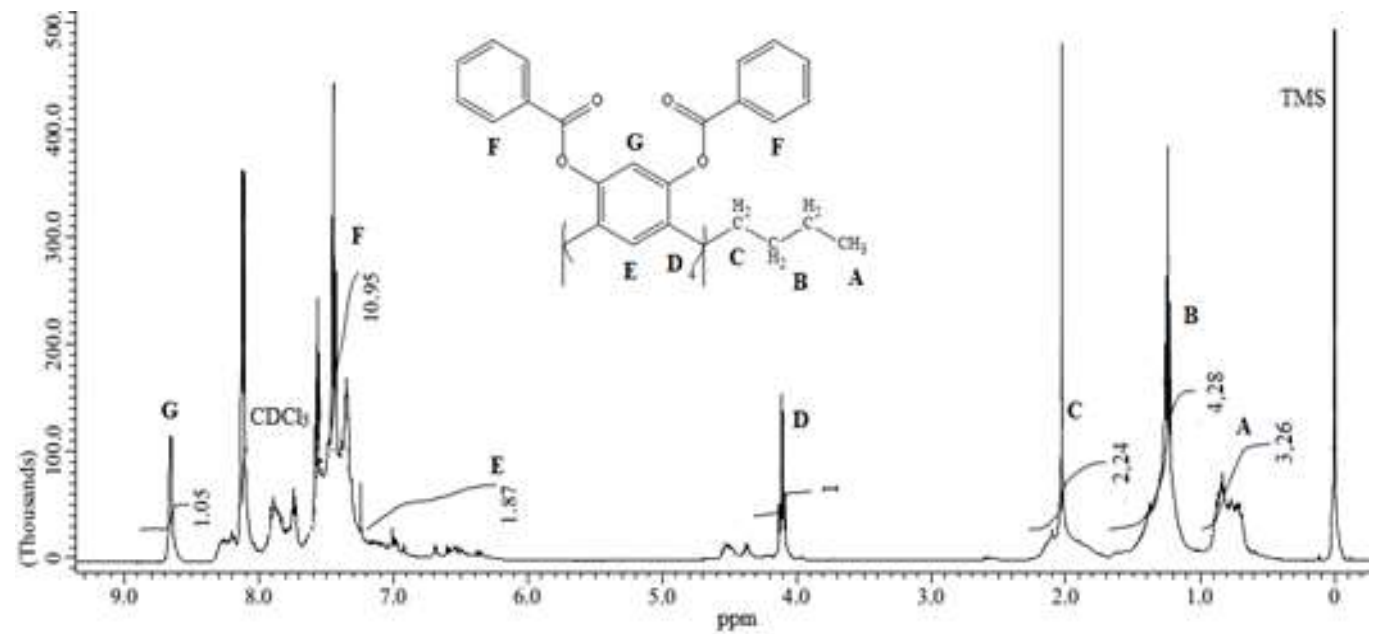

Fig.-2: ${ }^{1} \mathrm{H}$ NMR (500 MHz) Spectra for $\mathrm{CBCROB}$ in $\mathrm{CD}_{3} \mathrm{OD}$

\section{Synthesized CBCROC}

The CBCROC was obtained as a solid yellow powder $(66 \%)$, melting point $190-194{ }^{\circ} \mathrm{C}$. The melting point of $\mathrm{CBCROC}$ was lower than that of the $\mathrm{CBCR}$ because the $-\mathrm{OH}$ group of latter was replaced by a cinnamic group to form CBCROC. The CBCROC structure was again elucidated by FTIR and ${ }^{1} \mathrm{H}-\mathrm{NMR}$ spectrometers. The FTIR spectra showed that the CBCROC has no -OH moiety $\left(3400 \mathrm{~cm}^{-1}\right)$ but $\mathrm{C}=\mathrm{O}(1728$ $\left.\mathrm{cm}^{-1}\right)$ and $\mathrm{C}-\mathrm{O}\left(1134 \mathrm{~cm}^{-1}\right)$ ester moieties instead, indicating the successful synthesis. The ${ }^{1} \mathrm{H}-\mathrm{NMR}$ spectrum $\left(\mathrm{CDCl}_{3}\right.$ solvent) of the compound is depicted in Fig.-3, showing the proton resonance of $-\mathrm{CH}_{3}$ $(0.87 \mathrm{ppm}),-\mathrm{CH}_{2}(1.35$ and $2.00 \mathrm{ppm})$, proton bridge calix[4]-resorcinarene $(4.43 \mathrm{ppm}),-\mathrm{CH}=\mathrm{CH}-(6.56$ $\mathrm{ppm})$ aromatic of the benzoyl group $(7.31 \mathrm{ppm})$, and the aromatic benzene $(7.14$ and $7.59 \mathrm{ppm})$. This chemical structure elucidation reveals that the $\mathrm{CBCROB}$ compound has been successfully synthesized.

\section{UV Absorption Tests}

The UV spectra of the three synthesized compounds: CBCR, CBCROB, and CBCROC, are summarized in Table-1. It showed that these three compounds absorb in the UVB region spectrum; the CBCROB and the CBCROC absorb in the UVC region as well. The CBCROC indicates much higher SPF values as compared to that of $\mathrm{CBCR}$ and $\mathrm{CBCROB}$ because the $\mathrm{CBCROC}$ chemical structure has greater electron resonance 
RASĀYAN J. Chem.

Vol. 14 | No. 3 |1521-1527| July - September | 2021

that decreases the band gap between HOMO and LUMO, resulting in the increase of absorbed UV intensity and also SPF values. We suggest that CBCROC is the best sunscreen candidate amongst the three synthesized products.

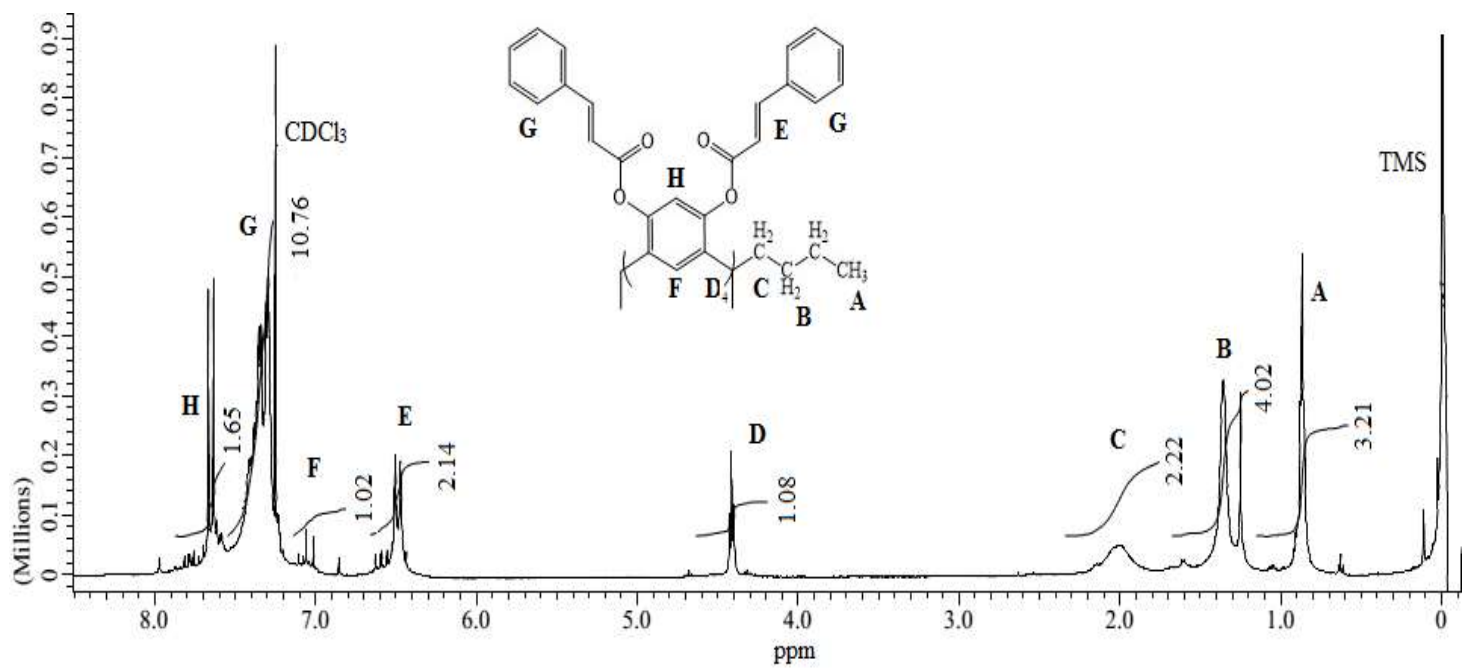

Fig.-3: ${ }^{1} \mathrm{H}$ NMR (500 MHz) Spectra for CBCROC in $\mathrm{CD}_{3} \mathrm{OD}$

Table-1: Ultraviolet Absorption Spectra and the Respective Sun Protection Factor (SPF)

\begin{tabular}{c|c|c|c|c}
\hline \multirow{2}{*}{ Name of Compound } & \multicolumn{2}{|c|}{ Maximum Wavelength Absorption (nm) } & \multirow{2}{*}{ SPF } \\
\cline { 2 - 5 } & UVC & UVB & UVA & \\
\hline CBCR & - & 286 & - & 3,80 \\
\hline CBCROB & 255 & 280 & - & 1,78 \\
\hline CBCROC & 275 & 285 & - & 380 \\
\hline
\end{tabular}

\section{Photostability Tests}

The CBCROC stability test was carried out under irradiation of the UVB spectrum towards CBCROC over various times, and the absorbance (Fig.-4) was compared to that of the cinnamon tetrapropoxycalix[4]arene (Fig.-5). This result showed that CBCROC has lower photostability than that of the cinnamon tetrapropoxycalix[4]arene, due to ester moiety that is not stable towards the light. However, it has a higher absorbance as compared with the cinnamoyltetra-propoxycalix[4] arena, meaning that the CBCROC is potential as a sunscreen active compound.

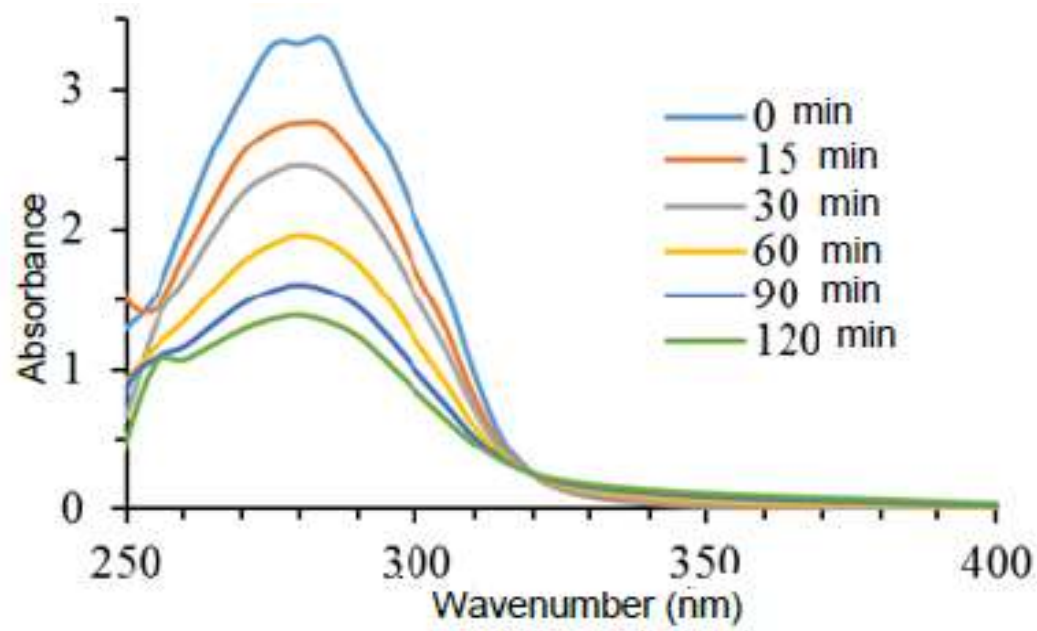

Fig.-4: Spectra Photostability CBCROC 
RASĀYAN J. Chem.

Vol. 14 | No. 3 |1521-1527| July - September | 2021

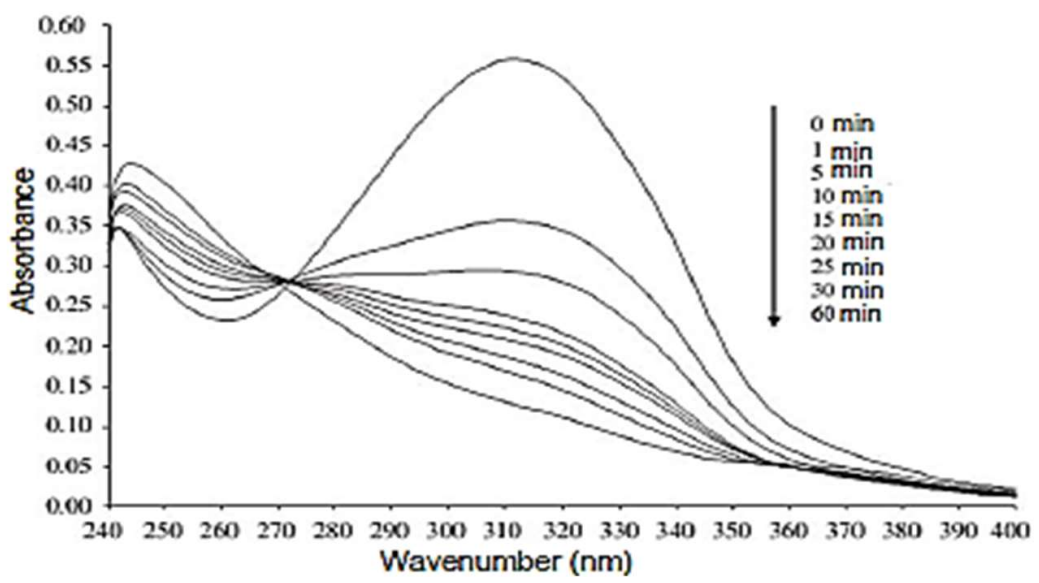

Fig.-5: Spectra Photostability, cinnamon tetrapropoxycalix[4]arene

\section{CONCLUSION}

CBCR compound has been synthesized and gives $97 \%$ in yield, while the synthesis of CBCROB and CBCROC compounds from this synthesized CBCR give 46 and $66 \%$ in yield, respectively. The SPF value of $50 \mathrm{ppm}$ of CBCR, CBCROC, and CBCROB were $1.78 ; 3.80$ and 380 , respectively. The SPF value of CBCROB was greatest compared to $\mathrm{CBCR}$ and $\mathrm{CBCROC}$, thus $\mathrm{CBCROB}$ compound was the best candidate as sunscreen, in spite of the relatively low photostability.

\section{ACKNOWLEDGEMENT}

The authors would like to thank the Ministry of Research, Technology and Higher Education of the Republic of Indonesia for funding this research through the program of Pendidikan Magister Menuju Doktor untuk Sarjana Unggul.

\section{REFERENCES}

1. X. Wang, Y. M. Zhang, and Y. Liu, Journal of the American Chemical Society, 137(13), 4543(2015), https://doi.org/10.1021/jacs.5b01566

2. P. Sherry, Rasayan Journal of Chemistry, 12(1), 379(2019), https://doi.org/10.31788/RJC.2019.1211063

3. A. A. Ortiz, B. Yan, and J.A. D'Orazio, Molecules, 19(5), 6202(2014), https://doi.org/10.3390/molecules 19056202

4. J. D'Orazio, S. Jarrett, A. A. Ortiz, and T. Scott, International Journal of Molecular Sciences, 14(6), 12222(2013), https://doi.org/10.3390/ijms140612222

5. T. M. Rünger, The Journal of Investigative Dermatology, 136(9), 1751(2016), https://doi.org/10.1016/j.jid.2016.04.001

6. U. Panich, Sittithumcharee, N. Rathviboon, and S. Jirawatnotai, Stem Cells International, 1(1), 1(2016), https://doi.org/10.1155/2016/7370642

7. D.L. Narayanan, R.N. Saladi, and J.L. Fox, International Journal of Dermatology, 49(9), 978(2010), https://doi.org/10.1111/j.1365-4632.2010.04474.x

8. B.I.G.M. Ngurah, Jumina, C. Anwar, Sunardi, and Mustofa, Indonesian Journal of Chemistry, 17(1), 63(2017), https://doi.org/10.22146/ijc.23575

9. J. Chou, T.J. Robinson, and H. Doan, Journal of Analytical Bionalytical Techniques, 8(2), 4(2017), https://doi.org/10.4172/2155-9872.1000355

10. R.R. Korać, and K.M. Khambholja, Pharmacognosy Review, 5(10), 164(2011), https://doi.org/10.4103/0973-7847.91114

11. D. Ratnasooriya, R.N. Pathirana, R.N.N. Gamage, K.B. Hasanthi, and S.K. Hettihewa, Imperial Journal of Interdisciplinary Research, 3(1), 2225(2017)

12. H. Suwito, Jumina, Mustofa, A.N. Kristanti, and N.N.T. Puspaningsih, Journal of Chemical Pharmaceutical Research, 6(5), 1076(2014), https://doi.org/10.1002/chin.201507329

13. A. Solankee, G. Patel, S. Solankee, Rasayan Journal of Chemistry, 1(3), 591(2008) 
RASĀYAN J. Chem.

Vol. 14 | No. 3 |1521-1527| July - September | 2021

14. Qian, X. Qiu, and S. Zhu, ACS Sustainable Chemistry Engineering, 4(7), 4027(2016), https://doi.org/10.1021/acssuschemeng.6b00934

15. N. Madad, L. Chebil, C. Sanchez, M. Ghoul, Rasayan Journal of Chemistry, 4(1), 189(2011)

16. C.A. Downs, E.K. Winter, R. Segal, J. Fauth, S. Knutson, O. Bronstein, F.R. Ciner, R. Jeger, Y. Lichtenfeld, C.M. Woodley, P. Pennington, K. Cadenas, A. Kushmaro, and Y. Loya, Archives of Environmental Contamination Toxicology, 70(2), 265(2016), https://doi.org/10.1007/s00244-015$\underline{0227-7}$

17. H. Darmokoesoemo, H. Setyawati, A.T.A. Ningtyas, H.S. Kusuma, Rasayan Journal of Chemistry, 10(2), 313(2017), https://doi.org/10.7324/RJC.2017.1021561

18. T. Kusumaningsih, Jumina, D. Siswanta, and Mustofa, Indonesian Journal of Chemistry, 10(1), 122(2010), https://doi.org/10.22146/ijc.21491

19. P.K. Lo, and M. S. Wong, Sensors, 8(9), 531(2008), https://doi.org/10.3390/s8095313

20. A.M. Ibrahim, S. Arunachalam, Rasayan Journal of Chemistry, 12(3), 1219(2019), https://doi.org/10.31788/RJC.2019.1235172

21. H.M. Chawla, N. Pant, S. Kumar, S. Mrig, B. Srivastava, N. Kumar, and D. StC. Black, Journal of $\begin{array}{lllll}\text { Photochemistry Photobiology B } & \text { Biology, 25(2011), }\end{array}$ https://doi.org/10.1016/j.jphotobiol.2011.06.007

22. K. Chennakesavulu, M. Basariya, P. Streedevi, G.B. Raju, S. Prabhakar, and S.S. Rao, Thermochimica Acta, 515(1), 24(2011), https://doi.org/10.1016/j.tca.2010.12.012

23. C. Walters, A. Keeney, C. Wigal, and R. Cornelius, Journal of Chemical Education, 74(1), 99(1997), https://doi.org/10.1021/ed074p99

[RJC-5972/2020] 